\title{
SUSTAINABLE AGRICULTURAL LAND USE IN THE POST-SOCIALIST CAMP COUNTRIES: MONITORING AND EVALUATION
}

\author{
Olena Kotykova ${ }^{1}$, Oleksandr Kuzmenko² ${ }^{\text {, Iryna Semenchuk }}{ }^{3}$
}

\begin{abstract}
The purpose of the article - to carry out the monitoring and evaluation of agricultural land use sustainability in the post-socialist camp countries. Methodology. During the study, the following methods were used: dialectical, abstract and logical, system analysis, index, and graphical comparison. Monitoring and evaluating of the agricultural land use sustainability involves periodic tracking relevant indicators based on available official statistics, central authorities' information, local authorities and carrying out, on the basis of monitoring, the ranking in the postsocialist camp countries by comparing the obtained results with their best values. Monitoring and evaluating of the agricultural land sustainability conducted to monitor the process of sustainable agricultural development goals implementation, problems' identification of regions agricultural land use and their causes, improving the efficiency of administrative decisions of central executive authorities, local authorities and the land market actors. Elements of scientific innovation. Existing methods for determining the integral indicator for comparing the land use sustainability and own method was suggested, by which the relevant calculations and conclusions were made. The proposed methodology ensures the implementation of appropriate objectives and indicators for monitoring the Global Sustainable Development Goals 2016-2030 achievement in Ukraine. Practical significance. The availability of the integral environmental and economic indicators at the macro level is ideal for people who make decisions in terms of consideration of the environmental factors on the country's development. The main goal of an integral indicator for comparing the sustainability of land use development in the regions of Ukraine creating is to ensure the possibility of ranking these regions in order of their total potential decreasing and thus defining "depressed" for providing the state aid to them. Conclusions. According to the given methods, it has been proved that agricultural land use in the countries of the post-socialist camp has a positive dynamics but the sustainability indicators for all indicators have not achieved yet. It has been defined that Estonia, Latvia, and Slovenia got the first three places; and Croatia, Lithuania, and Romania got the last places in the ranking of sustainability of the agricultural land use for the countries of the post-socialist camp. In accordance with settlements for solving the problems in the area of agricultural land use, the state should focus on less developed regions where the environmental situation is difficult, productivity and land return reduced, slowed population growth, and which have an excessive migration.
\end{abstract}

Key words: sustainable development, agricultural land use, method, methodology, region, indicators.

JEL Classification: C83, O52, Q01, Q15, R11

\section{Introduction}

In September 2015, in a framework of $70^{\text {th }}$ UN General Assembly session in New York, UN Summit for the adoption of the Development Agenda beyond 2015 was held. The summit is seen by the international community as an event of historic significance. Summit's problems covered all aspects of socio-economic development, national competitiveness, environmental and energy security and a global partnership for development, and the volume of thorough preparatory work had no precedent in history. After the summit before the UN Member Countries, facing new challenges identified adapt global goals and their monitoring. In Ukraine, there also has started work on sustainable development goals establishing, for 2016-2030 years, on the relevant targets and indicators for monitoring of the objectives achievement (UNU, 2017).

\footnotetext{
Corresponding author:

${ }^{1}$ Mykolayiv National Agrarian University, Ukraine.

E-mail: kotikova@i.ua

ORCID: http://orcid.org/0000-0003-1420-1500

${ }^{2}$ Petro Mohyla Black Sea National University, Ukraine.

E-mail: oleksandr.kuzmenko@chmnu.edu.ua

${ }^{3}$ Petro Mohyla Black Sea National University, Ukraine.

E-mail: irina.semenchuk@chmnu.edu.ua
} 
Currently, FAO has developed a Global Strategy for agricultural and rural statistics improving (FAO, 2017), in which various tasks will be implemented, including the task of defining parameters and indicators for food security monitoring (SDG 2), and - the global warming, biofuels, and environment.

The initiative on developing the Global Strategy for improving agricultural and rural statistics was a response to the decline in the quantity and quality of agricultural statistics. The purpose of the Global Strategy is to provide access to national and international statistical systems to obtain baseline data for SDG monitoring. However, the system of indicators is not yet presented by FAO and, therefore, not monitored. In Ukraine, at the official level, there is also no monitoring and evaluation of sustainable agricultural land use in Ukraine's regions.

\section{Methodology and methods}

The most authoritative foreign researchers on the sustainable development problems are Donella H. Meadows (2004), G. Brundtland (2002), M. Ashby (2015), N. Droste (2016), K. Fiorella (2016) and others. However, these researchers did not conduct the investigations of agricultural land use sustainability in Ukraine.

Domestic scientists offer different approaches to indicators system building for sustainability assessment. The most convenient way, from the viewpoint of the decision-making, is the definition of a single integrated indicator, but in respect to the methodology, it is very difficult to develop this indicator.

Nowadays, about three thousand ecological indicators are developed and used in practice in the world, and more than $2 / 3$ of them are partial ecological indicators. The existence of such a large number of environmental parameters requires their appropriate classification for more targeted and effective use of indexes and indicators in identifying and solving the specific range of environmental challenges.

The availability of the integral environmental and economic indicators at the macro level is ideal for people who make decisions in terms of consideration of the environmental factors on the country's development. The researchers can judge the degree of the stability of the country, ecological development trajectories according to only one such indicator. Therefore, this indicator can be a kind of analogue of GDP, GNP, national income, with the help of which the success of economic development and economic prosperity is often measured. However, at present, there is no universal integral indicator of sustainability.

In the prior studies (Kotykova, 2012), we presented the results of critical analysis and synthesis of existing approaches and methodologies for regional development assess. In previously defined ones, it should be provided a new method of monitoring and evaluation of the state regional policy implementation (The Method of the State Regional Policy Implementation Monitoring and Evaluation, 2015). According to the socio-economic development monitoring by 2015 , by the list of measure's indicators, specified in the Order of monitoring and evaluation of implementation of the state regional policy (The Procedure of the State Regional Policy Implementation Monitoring and Evaluation, 2015), the results are monitored in 12 areas: the economic and social cohesion; economic efficiency; investment and innovation development and foreign economic cooperation; the financial self-sufficiency; small and medium enterprises; labour market efficiency; infrastructure development; renewable energy and energy efficiency; accessibility and quality of education services; availability and quality of services in health care; social protection and safety; environmental management and environmental quality.

The rating evaluation is performed by comparing the deviation values of each concrete region of their best values in the respective regions (reporting) period and the corresponding regions ranging from the $1^{\text {st }}$ to $27^{\text {th }}$ place. The rating evaluation is based on the parameters relative deviations calculation of each region from maximum and minimum values of such parameters in the other regions, by the formula:

$$
R_{j}=\sum_{i=1}^{n} \frac{x_{\text {maxi }}-x_{i j}}{x_{\text {maxi }}-x_{\text {mini }}}+\sum_{i=1}^{n} \frac{x_{i j}-x_{\text {mini }}}{x_{\text {maxi }}-x_{\text {mini }}},(1)
$$

where $R_{j}$ - the sum of ratings of a particular region for each of the indicators, characterized the area of activity; $x_{i j}$ - the value of i-indicator for j-region; $x_{\operatorname{maxi}}-$ the maximum value of $\mathrm{i}$-indicator; $x_{\text {mini }}-$ the minimum value of i-indicator.

The formula's first part is used for indicators' evaluation, which increase is positive (for example, the volume of industrial output per capita), the second part - for indicators' evaluation, which increase has a negative value (for example, the amount of unpaid wages). Determining the arithmetic mean of the rating sum of the particular region by all annual assessment indicators, describing an area of activity, based on a formula:

$$
R_{c p j}=\frac{R_{j}}{n},(2)
$$

where $R_{c p j}$ - the arithmetic mean of the rating sum of the particular region by all assessment indicators of an activity area; $n$ - the number of indicators, which are calculated by different directions.

The indicators' calculations determined the integrated grade as the average value of the rating sum of a particular region in all directions by the formula:

$$
I_{j}=\frac{\sum_{1}^{m} R_{c p j}}{m},(3)
$$

where $I_{j}$ - the average value of the rating sum of a particular region in all directions; $m$ - the number of directions, for which the calculation was made. 
It should be noted that some of the complex rating evaluation indicators of socio-economic development by 2015 , which are published by the Ministry of Regional Development, Construction and Housing and Communal Services of Ukraine (The Socio-Economic Development Monitoring in 2015, 2016) can be considered as partially reflecting the level of agricultural land use sustainability. However, the indicators are scattered in different directions, partly presented in the report and not allow monitoring and making a holistic assessment of the agricultural land use sustainability of Ukraine's regions.

On the other hand, the Methodology mentioned above is used to determine the effectiveness of the state regional policy implementation. The main purpose of monitoring and evaluating the agricultural land use sustainability of Ukraine's regions is to allow their rankings and determination as "depressed" that require implementation of the appropriate measures for sustainable development goals achievement.

Since the official approved procedure of monitoring and evaluating the sustainability of agricultural land use regions of Ukraine does not exist, we propose to conduct such monitoring on the basis of the methodology substantiated above (FAO, 2017) with the necessary modifications that meet the sustainable development goals of Ukraine for 2015-2030.

Methodological explanations for Figure 2.

1.1. The share of arable land in the farmland square the percentage of arable land of agricultural land:

$$
1.1=\frac{A_{g} L}{A_{r} L},(4)
$$

$A_{g} L$-agricultural land is defined as land systematically used to produce agricultural products; it includes arable land, fallow, permanent crops, hayfields, and pastures. Agricultural lands may be owned, rented, and may be used on a temporary or permanent basis by agricultural enterprises, and individuals; $A_{r} L$ - arable land - land plots that are permanently cultivated and used for agricultural crops including permanent grasses and clean fallow, areas of hothouses and greenhouses. Arable land doesn't include hayfields and pastures ploughed up for full improvement and when they are permanently used under grass fodder crops for hay-mowing and livestock grazing, as well as inter-row spaces in orchards used for sowing.

1.2. Monetary valuation of a hectare of arable land (normative monetary value per hectare of arable land):

\section{2. $=R \cdot P \cdot T,(5)$}

$R$ - rental income on arable land; $P$ - price quintals of grain; $T-$ a term of rental income capitalization (33 years).

\subsection{Forest area:}

1.3. $=\frac{F l}{T l},(6)$

$\mathrm{Fl}$ - forest land; $\mathrm{Tl}$ - the total land area.
1.4. Inter-regional migration - the difference between the number of arrivals in an area and the number of departures abroad.

1.5. The rate of natural population growth in rural areas the difference between live births and the number of deaths.

1.6. Average monthly nominal wage in agriculture. Nominal wages - payment to employees in cash and kind for time worked or work done, tariff rates (salaries), bonuses, allowances, and other payments. It includes mandatory deductions from employee salaries, income tax, single social tax, war tax.

\subsection{Supply of housing in rural areas:}

$$
\text { 1.4. }=\frac{H s}{R p},(7)
$$

$H s$ - the housing stock - a set of premises, including residential buildings, special buildings (dormitories, shelters, homes for elderly and disabled people - adults and children, children's homes, and boarding schools), apartments, office accommodation, other accommodation in buildings suitable for living; $R p$ - rural population - people living in rural areas.

1.8. Agricultural output per 100 hectares of farmland - production crop and animal production total production volume in physical terms is estimated by dividing the production volume by agricultural land for the reporting year.

\subsection{Land return:}

$$
\text { 1.9. }=\frac{1.2}{A p},(8)
$$

Agricultural products (at constant prices) - the value of livestock and crop production.

1.10. Per capita agricultural production. Per capita crop and animal production is estimated by dividing the production volume by the average annual number of present population for the reporting year.

1.11. Polluted water into surface waters - the volume of allowable emission of non-treated and contaminated waste (industrial and municipal) discharged into surface waters.

1.12. Emissions of harmful substances into the atmosphere per $1 \mathrm{~km}^{2}$ - air emissions, total and carbon dioxide emissions.

1.13. The wastes generation per $1 \mathrm{~km}^{2}$. Waste - any substance, materials made as a result of the production or consumption, as well as goods (products) that wholly or partially lost their consumer properties and have no further use for the place of their creation and from which the owner should get rid of by recycling or removal.

\section{Data and estimation procedures}

Monitoring and evaluation of the agricultural land use sustainability involve periodic tracking of relevant indicators based on available official statistics, information of central authorities, local authorities and, 


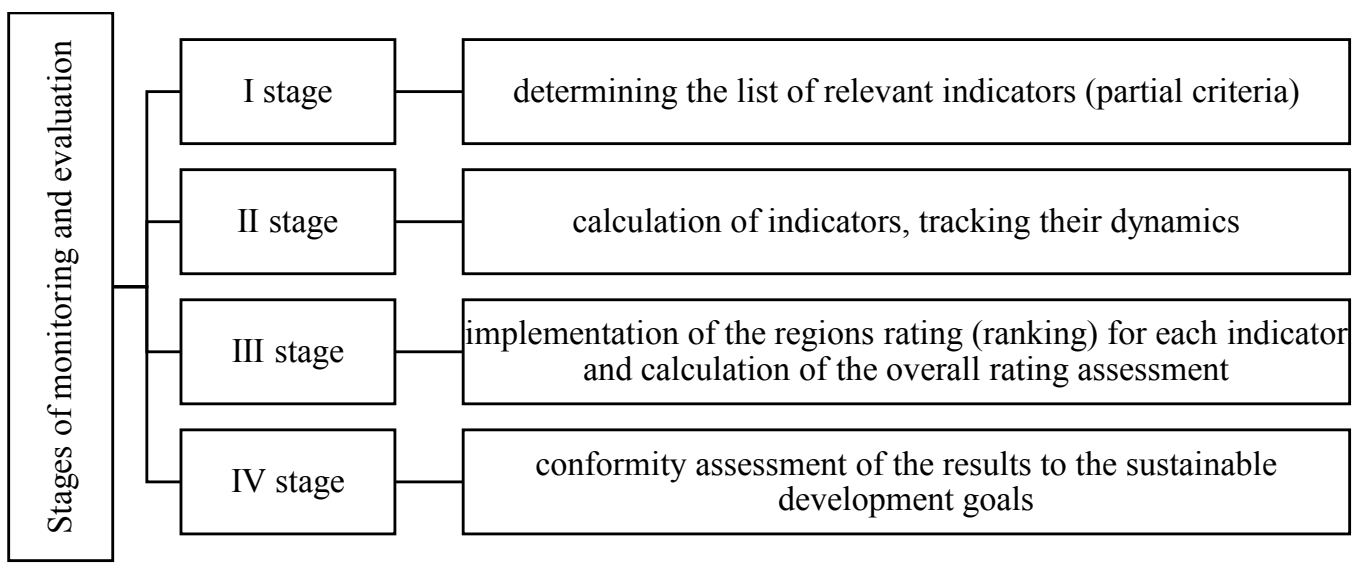

Figure 1. The monitoring and evaluating stages of land use sustainability

Source: created by the authors

on the basis of monitoring, carrying out the ranking of Ukrainian regions by comparing the obtained results with their best values. Monitoring and evaluation of the agricultural land sustainability are conducted to monitor the process of sustainable agricultural development goals implementation, problems' identification of regions agricultural land use and their causes, improving the efficiency of administrative decisions of central executive authorities, local authorities and the land market actors.

Given the goals and objectives of monitoring, we can identify four stages of monitoring and evaluating the agricultural land use sustainability (Figure 1).

At the firststage, in order to determine the list of relevant indicators, it's necessary: to justify the assessment criteria (which information should be available for simple calculations, there should be a few, but they must describe, as much as possible, the development of land areas); to develop such methodology for calculating the integral index that organizing by different methods did not significantly affect the position in the ranking. In addition, it should be quite simple and clear, and partial indicators, obtained during the calculation of integrated indicators, should not be just relative ratios but have economic content.

Since, as noted above, the indicator system should reflect the level of achievement of global Sustainable Development Goals 2015-2030, and then to the partial list of criteria, in our view, should include the following parameters (Figure 2): growth class or monetary evaluation of soil per hectare of farmland; the share of arable land in the farmland; forested area; the volume of agricultural production per 100 hectares of farmland; land return; the volume of polluted water in water surface; emissions of harmful substances into the air; formation of toxic industrial waste; the volume of agricultural production per capita; interregional migration; natural population growth in rural areas; average nominal wages; provision of housing.
As an integral indicator of the land use sustainability in Ukraine (at the macro- and meso-levels) according to the analogue to the green GDP, we propose to calculate the indicator of the gross agricultural production per capita taking into account the economic losses from soil pollution and other forms of anthropogenic influence:

$$
S D_{l u}=\frac{G A P-E L}{P},(9)
$$

However, despite the fact that in Ukraine the population tends to decrease, to apply the indicator to keep track of the dynamics of the land use sustainability is incorrect because with other conditions remaining the same, or even with some deterioration in their values, the decrease in population will lead to the increased values of the land use sustainability, which denies the essential meaning of the sustainability. Therefore, the integrator should be used as the basic integral indicator of the land use sustainability and for comparisons at the regional level. For the assessment of the changes in the land use sustainability over time, formula 2 can be used:

$$
S D_{l u}=\frac{G A P-E L}{A L},(10)
$$

It is clear that the area of the agricultural land, as well as the population, may be reduced; however, if such changes are the results of the anthropogenic impact, the consequences of this will be reflected in the formula through economic losses (EB). Other reasons for the withdrawal of agricultural lands from circulation have positive environmental or social consequences (e.g., for the establishment of the protected area) and, therefore, they do not distort the results of calculation of the indicator.

Another situation can happen when the agricultural land area will be expanded. However: firstly, for Ukraine, considering the indicators of agricultural land development, it is impossible at least in significant quantities; secondly, in this case, the indicator $\mathrm{CP}_{3}$ will be decreased (with other conditions remaining the same). 


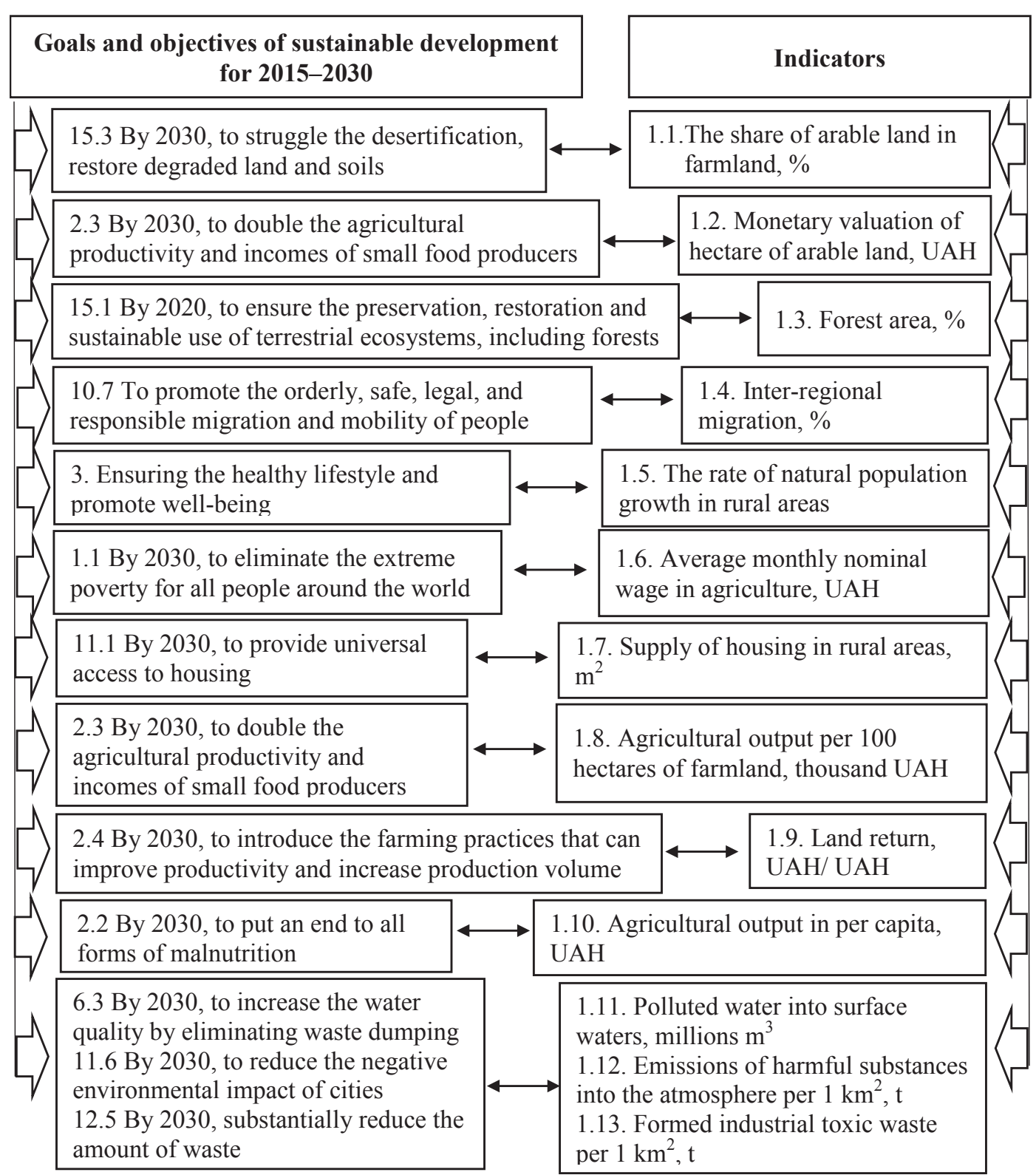

Figure 2. The system for monitoring and assessment of the agricultural land use sustainability indicators of Ukraine's regions

Source: created by the authors

\section{Results}

At the second stage, the calculation of the proposed list of indicators is provided. The data for 2006 and 2013 are presented in Tables 1, 2, and 3.

The range of these fluctuations according to the indicators, calculated by different methods, in most countries ranges from zero to one and only in Slovakia and Ukraine the fluctuation is two units. The value of the indicator in Slovenia is significantly different from the indicators of other countries. The excess in the value of the indicator $\mathrm{SD}_{\mathrm{lu}(\mathrm{I})}$ compared to $\mathrm{SD}_{\mathrm{lu}(\mathrm{II})}$ is set in all countries.

Positive changes in most regions are found in two partial indicators: the land return (a negative trend is noted in the AR of Crimea, Donetsk, Zakarpattia, and Lviv regions) and the volume of polluted water into surface waters (a negative trend is noted in the AR of Crimea and Sumy region).

The dynamics study of the specified indicators shows the improvements in all regions according to six partial indicators: monetary evaluation of farmland per hectare (the largest increase is found in the Cherkasy region and the lowest one - in the Chernihiv region); average nominal wages (the largest gain is set in the Kyiv region and the lowest - in the Odesa region); the volume of agricultural production per 100 hectares of farmland (the largest increase 
Table 1

The land use sustainability assessment of the post-socialist countries by the integral indicator in 2013, units of national currency

\begin{tabular}{|l|c|c|c|}
\hline \multicolumn{1}{|c|}{ Countries } & $\begin{array}{c}\text { The calculation } \\
\text { of } \mathrm{SD}_{\mathrm{lu}} \text { by formula }\end{array}$ & $\begin{array}{c}\text { The calculation } \\
\text { of } \mathrm{SD}_{\mathrm{lu}} \text { by formula } 10\end{array}$ & $\begin{array}{c}\text { Values obtained by formula } 10 \text { in relation } \\
\text { to the values obtained by formula } 9(+,-)\end{array}$ \\
\hline Bulgaria & 303,7 & 628,6 & 324,9 \\
\hline Latvia & 178,3 & 302,6 & 124,3 \\
\hline Lithuania & 576,9 & 730,2 & 153,3 \\
\hline Poland & 423,8 & 1487,2 & 1063,4 \\
\hline Romania & 1547,8 & 3521,8 & 227,5 \\
\hline Slovakia & 79,0 & 306,5 & 0,0 \\
\hline Slovenia & 0,0 & 0,0 & 6228,7 \\
\hline Croatia & 1641,5 & 7870,2 & $\ldots$ \\
\hline Czech Republic & $\ldots$ & $\ldots$ & 146,4 \\
\hline Estonia & 133,8 & 280,2 & 746,5 \\
\hline Ukraine & 2697,6 & 3444,1 & \\
\hline
\end{tabular}

Source: calculated by the authors according to the State Statistics Service of Ukraine and Federal State Statistics Service

Table 2

Monitoring and Evaluating Indicators (partial criteria)

of the agricultural land use sustainability of regions of Ukraine in 2006

\begin{tabular}{|c|c|c|c|c|c|c|c|c|c|c|c|c|c|}
\hline \multirow{2}{*}{ Regions } & \multicolumn{13}{|c|}{ Indicators } \\
\hline & 1.1 & 1.2 & 1.3 & 1.4 & 1.5 & 1.6 & 1.7 & 1.8 & 1.9 & 1.10 & 1.11 & 1.12 & 1.13 \\
\hline AR of Crimea & 79.1 & 11191 & 12.4 & 110.8 & -4.5 & 952 & 16.7 & 210.5 & 0.19 & 1337 & 80 & 4.7 & 43.28 \\
\hline Vinnytsia & 90.5 & 10018 & 14.2 & 78.2 & -13.2 & 793 & 31.3 & 300.4 & 0.30 & 3216 & 2 & 8.0 & 0.03 \\
\hline Volyn & 70.3 & 9069 & 34.3 & 97.2 & -4.7 & 773 & 21.6 & 323.5 & 0.36 & 2720 & 1 & 2.8 & 0.03 \\
\hline Dnipropetrovsk & 93.5 & 9852 & 6.0 & 109.9 & -11.5 & 1139 & 26.1 & 263.2 & 0.27 & 1729 & 660 & 39.9 & 29.57 \\
\hline Donetsk & 86.9 & 10556 & 7.7 & 92.8 & -11.7 & 1202 & 23.7 & 270.4 & 0.28 & 1084 & 1374 & 71.5 & 239.53 \\
\hline Zhytomyr & 74.8 & 6235 & 35.5 & 77.7 & -13.7 & 793 & 26.4 & 233.7 & 0.38 & 2430 & 23 & 2.5 & 0.82 \\
\hline Zakarpattia & 47.6 & 7946 & 56.5 & 62.8 & -0.1 & 868 & 22.1 & 506.6 & 0.64 & 1684 & 13 & 5.5 & 0.32 \\
\hline Zaporizhzhia & 88.4 & 10250 & 4.3 & 86.2 & -11.0 & 1091 & 25.0 & 177.4 & 0.17 & 2052 & 457 & 13.9 & 289.91 \\
\hline Ivano-Frankivsk & 72.2 & 8653 & 45.6 & 85.7 & -3.7 & 923 & 23.3 & 493.6 & 0.57 & 1775 & 26 & 22.9 & 3.68 \\
\hline Kyiv & 84.5 & 9684 & 23.7 & 104.6 & -15.3 & 1058 & 34.9 & 413.6 & 0.43 & 1429 & 16 & 7.2 & 5.64 \\
\hline Kirovohrad & 95.9 & 9722 & 7.3 & 53.5 & -12.0 & 819 & 26.3 & 211.2 & 0.22 & 3567 & 21 & 2.5 & 0.65 \\
\hline Luhansk & 72.6 & 8033 & 12.8 & 67.3 & -12.8 & 1022 & 24.2 & 159.8 & 0.20 & 1173 & 222 & 24.0 & 33.31 \\
\hline Lviv & 69.2 & 8064 & 31.7 & 90.8 & -5.6 & 923 & 22.7 & 404.5 & 0.50 & 1658 & 180 & 9.5 & 10.96 \\
\hline Mykolaiv & 91.1 & 7985 & 4.9 & 92.1 & -7.4 & 955 & 22.6 & 172.5 & 0.22 & 2530 & 29 & 2.8 & 22.09 \\
\hline Odesa & 86.5 & 8515 & 6.7 & 94.6 & -7.4 & 966 & 23.7 & 202.4 & 0.24 & 1946 & 183 & 4.2 & 0.08 \\
\hline Poltava & 90.0 & 10513 & 9.5 & 100.0 & -14.9 & 961 & 27.2 & 260.4 & 0.25 & 3208 & 5 & 6.6 & 0.33 \\
\hline Rivne & 72.6 & 9513 & 39.7 & 84.3 & -1.9 & 888 & 22.3 & 316.1 & 0.34 & 2386 & 25 & 2.9 & 0.52 \\
\hline Sumy & 78.9 & 8913 & 19.1 & 69.0 & -17.7 & 857 & 25.8 & 198.7 & 0.22 & 2354 & 10 & 3.3 & 73.66 \\
\hline Ternopil & 84.5 & 9612 & 14.4 & 72.4 & -8.3 & 727 & 23.3 & 298.2 & 0.31 & 2609 & 3 & 3.9 & 0.01 \\
\hline Kharkiv & 83.3 & 9847 & 13.2 & 124.5 & -12.5 & 974 & 23.3 & 228.8 & 0.23 & 1787 & 20 & 10.3 & 2.89 \\
\hline Kherson & 94.0 & 10480 & 5.3 & 67.8 & -5.6 & 800 & 21.6 & 196.2 & 0.19 & 3102 & 28 & 2.3 & 0.24 \\
\hline Khmelnytskyi & 81.3 & 10449 & 13.8 & 80.2 & -14.5 & 792 & 28.0 & 248.8 & 0.24 & 2642 & 7 & 2.8 & 0.10 \\
\hline Cherkasy & 93.8 & 12059 & 16.1 & 89.7 & -15.3 & 846 & 30.1 & 378.7 & 0.31 & 3742 & 20 & 5.0 & 0.13 \\
\hline Chernivtsi & 73.1 & 10301 & 31.8 & 110.0 & -3.1 & 819 & 22.7 & 414.6 & 0.41 & 2075 & 7 & 4.0 & 0.01 \\
\hline Chernihiv & 69.9 & 7398 & 22.4 & 83.6 & -23.0 & 790 & 29.3 & 188.1 & 0.26 & 3010 & 29 & 2.7 & 0.20 \\
\hline
\end{tabular}

Source: calculated by the authors according to the State Statistics Service of Ukraine

Note: See the list of indicators in Figure 2 
is found in the Cherkasy region and the lowest in the Luhansk region); the volume of agricultural production per person (the largest increase is found in the Cherkasy region and the lowest in the Donetsk region); supply of housing (the largest increase is found in the Kyiv region and the lowest in the Mykolaiv region); natural population growth in rural areas (the largest increase is found in the Odesa region and the least - in the Ivano-Frankivsk region).

Negative changes in most regions are found in four partial indicators: the share of arable land in the area of farmland (positive changes took place in Luhansk, Kherson, and Chernivtsi regions; the indicator value did not change in Kyiv and Zaporizhzhia regions); forested areas (positive changes took place in the AR of Crimea, Kyiv and Ivano-Frankivsk regions, and the indicator value did not change in Dnipropetrovsk, Donetsk, Odesa, and Kherson regions); emissions of harmful substances into the air (positive changes took place in Volyn, Dnipropetrovsk, Donetsk, Zaporizhzhia, and Sumy regions); formation of toxic industrial waste (positive changes took place in Zaporizhzhia and Sumy regions).
In terms of inter-regional migration, the positive trend observed in Vinnytsia, Volyn, Zhytomyr, Zakarpattia, IvanoFrankivsk, Kyiv, Kirovohrad, Lviv, Odesa, Rivne, Sumy, Ternopil, Kherson, Khmelnytskyi, and Chernivtsi regions.

Among post-socialist countries, Ukraine according to the indicator of sustainability ranks the first place according to the indicator calculated by the first method and the third place according to the indicator calculated by the second method (Figure 3 ).

Ranking of the regions in terms of the share of arable land in the farmland testifies positive changes in the ranking of Volyn, Dnipropetrovsk, Zhytomyr, Ivano-Frankivsk, Odesa, Poltava, and Rivne regions. The positions in the indicator ranking of Luhansk and Chernivtsi regions significantly reduced (Table 4-5).

By the indicator of monetary farmland evaluation improved the position in the ranking of Mykolaiv, Poltava, and Ternopil regions, and deteriorated - in Zakarpattia, Rivne, Khmelnytskyi, and Kherson regions.

In terms of forest areas the least of changes occurred - just in four regions: increased the Kyiv and Kharkiv regions rating, reduced - the Luhansk and Chernihiv regions rating.

Table 3

Monitoring and Evaluating Indicators (partial criteria) of the agricultural land use sustainability of regions of Ukraine in 2013

\begin{tabular}{|c|c|c|c|c|c|c|c|c|c|c|c|c|c|}
\hline \multirow{2}{*}{ Regions } & \multicolumn{13}{|c|}{ Indicators } \\
\hline & 1.1 & 1.2 & 1.3 & 1.4 & 1.5 & 1.6 & 1.7 & 1.8 & 1.9 & 1.10 & 1.11 & 1.12 & 1.13 \\
\hline AR of Crimea & 80.8 & 24651 & 11.5 & 109.0 & 0.5 & 2204 & 19.0 & 448.4 & 0.18 & 3353 & 93 & 5.0 & 98.90 \\
\hline Vinnytsia & 90.8 & 22067 & 14.3 & 86.2 & -9.6 & 2410 & 34.3 & 979.3 & 0.44 & 11014 & 1 & 8.6 & 109.7 \\
\hline Volyn & 73.1 & 19976 & 34.6 & 100.0 & -0.3 & 2008 & 25.1 & 765.8 & 0.38 & 6097 & 1 & 2.4 & 28.4 \\
\hline Dnipropetrovsk & 94.7 & 21701 & 6.0 & 85.7 & -6.5 & 2344 & 27.6 & 688.5 & 0.32 & 4584 & 325 & 35.9 & 9420.2 \\
\hline Donetsk & 87.8 & 23255 & 7.7 & 71.6 & -8.7 & 2581 & 26.0 & 645.2 & 0.28 & 2635 & 507 & 62.1 & 2006.9 \\
\hline Zhytomyr & 81.3 & 13732 & 37.7 & 85.9 & -8.9 & 2420 & 32.2 & 652.7 & 0.48 & 6643 & 3 & 3.0 & 22.5 \\
\hline Zakarpattia & 48.0 & 17599 & 56.8 & 70.3 & 3.2 & 2261 & 24.0 & 1072.1 & 0.61 & 3435 & 2 & 5.4 & 9.3 \\
\hline Zaporizhzhia & 88.4 & 22577 & 4.4 & 78.2 & -6.2 & 2052 & 27.1 & 447.1 & 0.20 & 5349 & 77 & 13.0 & 168.2 \\
\hline Ivano-Frankivsk & 76.4 & 19060 & 45.6 & 103.5 & -1.5 & 2560 & 25.7 & 1138.0 & 0.60 & 4062 & 1 & 18.2 & 121.4 \\
\hline Kyiv & 84.6 & 21331 & 23.1 & 153.6 & -10.1 & 2766 & 44.6 & 990.1 & 0.46 & 3272 & 3 & 9.9 & 85.5 \\
\hline Kirovohrad & 96.7 & 21415 & 7.7 & 75.0 & -7.7 & 2251 & 27.9 & 641.7 & 0.30 & 11561 & 5 & 3.0 & 1582.4 \\
\hline Luhansk & 72.1 & 17694 & 13.4 & 59.0 & -9.2 & 2126 & 26.2 & 382.5 & 0.22 & 2892 & 142 & 19.6 & 667.1 \\
\hline Lviv & 71.0 & 17762 & 31.8 & 91.6 & -2.5 & 2421 & 25.7 & 869.8 & 0.49 & 3470 & 46 & 10.9 & 121.6 \\
\hline Mykolaiv & 92.5 & 17588 & 5.1 & 79.8 & -3.5 & 2073 & 23.5 & 530.6 & 0.30 & 8023 & 25 & 3.4 & 94.5 \\
\hline Odesa & 88.8 & 18757 & 6.7 & 129.4 & -1.8 & 1770 & 27.1 & 514.8 & 0.27 & 4740 & 81 & 4.9 & 21.3 \\
\hline Poltava & 92.8 & 22853 & 9.9 & 93.9 & -10.6 & 2404 & 30.1 & 866.2 & 0.38 & 10952 & 5 & 6.1 & 200.3 \\
\hline Rivne & 77.7 & 20954 & 40.2 & 84.9 & 1.9 & 2296 & 24.0 & 829.3 & 0.40 & 5669 & 7 & 2.8 & 78.9 \\
\hline Sumy & 80.0 & 19633 & 19.3 & 77.6 & -13.5 & 2220 & 29.5 & 651.1 & 0.33 & 8271 & 27 & 3.3 & 28.4 \\
\hline Ternopil & 85.8 & 20043 & 14.6 & 79.5 & -5.9 & 2048 & 25.8 & 836.4 & 0.42 & 7488 & 2 & 4.2 & 48.9 \\
\hline Kharkiv & 84.2 & 21688 & 13.3 & 110.9 & -7.8 & 2396 & 26.4 & 671.5 & 0.31 & 5343 & 13 & 10.5 & 65.6 \\
\hline Kherson & 93.7 & 23151 & 5.3 & 69.9 & -2.8 & 2037 & 22.8 & 554.7 & 0.24 & 9123 & 2 & 2.6 & 12.2 \\
\hline Khmelnytskyi & 82.0 & 23016 & 13.9 & 87.5 & -10.9 & 2453 & 31.4 & 780.2 & 0.34 & 8793 & 1 & 3.9 & 53.9 \\
\hline Cherkasy & 94.3 & 26562 & 16.2 & 87.6 & -10.9 & 2488 & 33.4 & 1142.2 & 0.43 & 11821 & 8 & 7.2 & 49.2 \\
\hline Chernivtsi & 72.1 & 22685 & 31.9 & 120.3 & -0.5 & 2213 & 25.6 & 1007.5 & 0.44 & 4973 & 2 & 4.8 & 51.3 \\
\hline Chernihiv & 75.0 & 16295 & 23.2 & 81.6 & -18.5 & 2157 & 38.3 & 542.9 & 0.33 & 8777 & 17 & 2.9 & 21.1 \\
\hline
\end{tabular}

Source: calculated by the authors according to the State Statistics Service of Ukraine

Note: See the list of indicators in Figure 2 


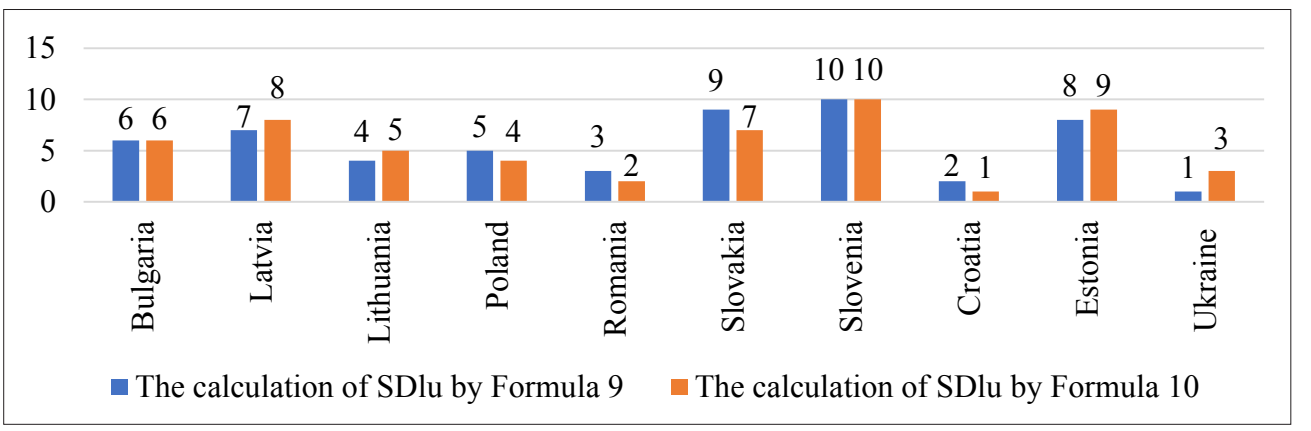

Figure 3. The land use sustainability assessment of the post-socialist countries by the integral indicator in 2013

Source: calculated by the authors according to the State Statistics Service of Ukraine and Federal State Statistics Service

Table 4

Partial rating criteria for sustainability of agricultural land use of Ukraine's regions monitoring and evaluating during 2006

\begin{tabular}{|l|c|c|c|c|c|c|c|c|c|c|c|c|c|}
\hline \multicolumn{1}{|c}{ Regions } & 1.1 & 1.2 & 1.3 & 1.4 & 1.5 & 1.6 & 1.7 & 1.8 & 1.9 & 1.10 & 1.11 & 1.12 & 1.13 \\
\hline AR of Crimea & 11 & 2 & 17 & 2 & 5 & 9 & 20 & 18 & 23 & 23 & 16 & 10 & 20 \\
\hline Vinnytsia & 20 & 9 & 13 & 18 & 15 & 17 & 2 & 9 & 11 & 3 & 2 & 14 & 2 \\
\hline Volyn & 4 & 16 & 5 & 7 & 6 & 21 & 19 & 7 & 7 & 7 & 1 & 4 & 2 \\
\hline Dnipropetrovsk & 22 & 10 & 22 & 4 & 10 & 2 & 9 & 12 & 13 & 19 & 21 & 21 & 18 \\
\hline Donetsk & 17 & 3 & 19 & 9 & 11 & 1 & 13 & 11 & 12 & 25 & 22 & 22 & 22 \\
\hline Zhytomyr & 9 & 25 & 4 & 19 & 16 & 17 & 7 & 15 & 6 & 11 & 11 & 2 & 12 \\
\hline Zakarpattia & 1 & 23 & 1 & 24 & 1 & 13 & 18 & 1 & 1 & 20 & 7 & 12 & 8 \\
\hline Zaporizhzhia & 18 & 8 & 25 & 13 & 9 & 3 & 11 & 22 & 25 & 15 & 20 & 18 & 23 \\
\hline Ivano-Frankivsk & 5 & 18 & 2 & 14 & 4 & 11 & 14 & 2 & 2 & 18 & 13 & 19 & 14 \\
\hline Kyiv & 15 & 13 & 8 & 5 & 19 & 4 & 1 & 4 & 4 & 22 & 8 & 13 & 15 \\
\hline Kirovohrad & 25 & 12 & 20 & 25 & 12 & 16 & 8 & 17 & 20 & 2 & 10 & 2 & 11 \\
\hline Luhansk & 7 & 21 & 16 & 23 & 14 & 5 & 12 & 24 & 22 & 24 & 19 & 20 & 19 \\
\hline Lviv & 2 & 20 & 7 & 11 & 6 & 10 & 15 & 5 & 3 & 21 & 17 & 15 & 16 \\
\hline Mykolaiv & 21 & 22 & 24 & 10 & 7 & 8 & 16 & 23 & 21 & 10 & 15 & 4 & 17 \\
\hline Odesa & 16 & 19 & 21 & 8 & 7 & 7 & 13 & 19 & 17 & 16 & 18 & 9 & 3 \\
\hline Poltava & 19 & 4 & 18 & 6 & 18 & 10 & 6 & 13 & 15 & 4 & 4 & 17 & 9 \\
\hline Rivne & 6 & 15 & 3 & 15 & 2 & 12 & 17 & 8 & 8 & 12 & 12 & 5 & 10 \\
\hline Sumy & 10 & 17 & 10 & 21 & 20 & 14 & 10 & 20 & 19 & 13 & 6 & 6 & 21 \\
\hline Ternopil & 14 & 14 & 12 & 20 & 8 & 22 & 14 & 10 & 10 & 9 & 3 & 7 & 1 \\
\hline Kharkiv & 13 & 11 & 15 & 1 & 13 & 6 & 14 & 16 & 18 & 17 & 9 & 16 & 13 \\
\hline Kherson & 24 & 5 & 23 & 22 & 6 & 19 & 19 & 21 & 24 & 5 & 14 & 1 & 7 \\
\hline Khmelnytskyi & 12 & 6 & 14 & 17 & 17 & 18 & 5 & 14 & 16 & 8 & 5 & 4 & 4 \\
\hline Cherkasy & 23 & 1 & 11 & 12 & 19 & 15 & 3 & 6 & 9 & 1 & 9 & 11 & 5 \\
\hline Chernivtsi & 8 & 7 & 6 & 3 & 3 & 16 & 15 & 3 & 5 & 14 & 5 & 8 & 1 \\
\hline Chernihiv & 3 & 24 & 9 & 16 & 21 & 20 & 4 & 21 & 14 & 6 & 15 & 3 & 6 \\
\hline
\end{tabular}

Source: calculated by the authors

Note: See the list of indicators in Figure 2

Contrary, the significant changes took place in the ranking in terms of interregional migration: most grown ranking in Ivano-Frankivsk, Zhytomyr, and Khmelnytskyi regions; Dnipropetrovsk, Donetsk, and Mykolaiv regions significantly reduced in terms of the ranking position.

In terms of natural population growth in rural areas, the most of the regions worsened their position in the ranking, the highest and lowest ranking, increased and reduced by five positions respectively in Volyn and Khmelnytskyi regions.
The biggest difference in the change of rating positions held in terms of average nominal wages. By 18 points dropped Zaporizhzhia and Odesa regions ranking, by 13 points increased Khmelnytskyi region ranking. Positions of Zakarpattia, Rivne, Ternopil, and Chernivtsi regions remained unchanged.

According to the rating of the housing supply, the position of the Mykolaiv region has increased significantly and the positions of Zhytomyr, Odesa, Sumy, and Chernihiv regions reduced a little. 
Vol. 5, No. 1, 2019

Baltic Journal of Economic Studies

Table 5

Partial rating criteria for sustainability of agricultural land use of Ukraine's regions monitoring and evaluating during 2013

\begin{tabular}{|l|c|c|c|c|c|c|c|c|c|c|c|c|c|}
\hline \multicolumn{1}{|c}{ Regions } & 1.1 & 1.2 & 1.3 & 1.4 & 1.5 & 1.6 & 1.7 & 1.8 & 1.9 & 1.10 & 1.11 & 1.12 & 1.13 \\
\hline AR of Crimea & 10 & 2 & 17 & 5 & 6 & 17 & 25 & 23 & 25 & 22 & 14 & 13 & 16 \\
\hline Vinnytsia & 19 & 9 & 13 & 12 & 18 & 8 & 3 & 6 & 7 & 3 & 1 & 17 & 17 \\
\hline Volyn & 5 & 16 & 5 & 7 & 1 & 24 & 20 & 12 & 11 & 12 & 1 & 1 & 6 \\
\hline Dnipropetrovsk & 24 & 10 & 22 & 14 & 12 & 11 & 10 & 13 & 16 & 18 & 16 & 24 & 25 \\
\hline Donetsk & 16 & 3 & 19 & 22 & 15 & 2 & 15 & 17 & 20 & 25 & 17 & 25 & 24 \\
\hline Zhytomyr & 11 & 25 & 4 & 13 & 16 & 7 & 5 & 15 & 4 & 11 & 3 & 5 & 5 \\
\hline Zakarpattia & 1 & 22 & 1 & 23 & 1 & 13 & 21 & 3 & 1 & 21 & 2 & 14 & 1 \\
\hline Zaporizhzhia & 17 & 8 & 25 & 19 & 11 & 21 & 12 & 24 & 24 & 14 & 12 & 21 & 20 \\
\hline Ivano-Frankivsk & 7 & 18 & 2 & 6 & 4 & 3 & 18 & 2 & 2 & 19 & 1 & 22 & 18 \\
\hline Kyiv & 14 & 13 & 9 & 1 & 19 & 1 & 1 & 5 & 5 & 23 & 3 & 18 & 14 \\
\hline Kirovohrad & 25 & 12 & 20 & 21 & 13 & 14 & 9 & 18 & 19 & 2 & 4 & 6 & 23 \\
\hline Luhansk & 3 & 21 & 15 & 25 & 17 & 19 & 14 & 25 & 23 & 24 & 15 & 23 & 22 \\
\hline Lviv & 2 & 20 & 7 & 9 & 7 & 6 & 17 & 7 & 3 & 20 & 11 & 20 & 19 \\
\hline Mykolaiv & 20 & 23 & 24 & 17 & 9 & 20 & 23 & 21 & 18 & 9 & 9 & 8 & 15 \\
\hline Odesa & 18 & 19 & 21 & 2 & 5 & 25 & 11 & 22 & 21 & 17 & 13 & 12 & 4 \\
\hline Poltava & 21 & 6 & 18 & 8 & 20 & 9 & 7 & 8 & 12 & 4 & 4 & 15 & 21 \\
\hline Rivne & 8 & 14 & 3 & 15 & 3 & 12 & 22 & 10 & 10 & 13 & 5 & 3 & 13 \\
\hline Sumy & 9 & 17 & 10 & 20 & 23 & 15 & 8 & 16 & 15 & 8 & 10 & 7 & 7 \\
\hline Ternopil & 15 & 15 & 12 & 18 & 10 & 22 & 16 & 9 & 9 & 10 & 2 & 10 & 8 \\
\hline Kharkiv & 13 & 11 & 16 & 4 & 14 & 10 & 13 & 14 & 17 & 15 & 7 & 19 & 12 \\
\hline Kherson & 22 & 4 & 23 & 24 & 8 & 23 & 24 & 19 & 22 & 5 & 2 & 2 & 2 \\
\hline Khmelnytskyi & 12 & 5 & 14 & 11 & 22 & 5 & 6 & 11 & 13 & 6 & 1 & 9 & 11 \\
\hline Cherkasy & 23 & 1 & 11 & 10 & 21 & 4 & 4 & 1 & 8 & 1 & 6 & 16 & 9 \\
\hline Chernivtsi & 4 & 7 & 6 & 3 & 2 & 16 & 19 & 4 & 6 & 16 & 2 & 11 & 10 \\
\hline Chernihiv & 6 & 24 & 8 & 16 & 24 & 18 & 2 & 20 & 14 & 7 & 8 & 4 & 3 \\
\hline
\end{tabular}

Source: calculated by the author

Note: See the list of indicators in Figure 2

In terms of agricultural production per 100 hectares of farmland, ranking positions of Crimea and Donetsk region increased the most; thus Poltava and Cherkasy regions significantly lost in the ranking. In terms of land return, the rating of the Donetsk region increased by eight positions, while Vinnytsia and Sumy regions lost four positions in the ranking. By indicator of agricultural production volume per capita, the rating equally decreased and increased (by five positions), respectively, in Sumy and Volyn regions.

The worst situation in the regions is in terms of indicator of polluted water volumes into surface waters - in all regions (except Volyn and Poltava regions where the rating has not changed) positions in the ranking declined. Contrary, in terms of emissions into the atmosphere, almost all regions rating improved (except Volyn, Poltava, and Rivne regions). In terms of the formation of toxic industrial waste Vinnytsia (15 points), Kirovohrad (12 points), and Poltava (12 points) regions significantly improved its positions; 14 points down the Sumy region rating.

Calculation of total rating assessment is proposed to be done according to previously created methodology (UNU, 2017). According to the calculations in 2013, the first three places in the ranking respectively received Zakarpattia, Volyn, Ivano-Frankivsk regions (Table 6).
Thus, the first two positions in the ranking of the regions did not change and, in the Ivano-Frankivsk region, the rating increased by five positions.

In Zakarpattia region, partial indexes are the highest by five of the thirteen indicators: the share of arable land in farmland, forest area, the rate of natural population growth, land return, and the formation of industrial toxic waste. In the Volyn ( $2^{\text {nd }}$ place $)$, Kyiv ( $9^{\text {th }}$ place $)$, and Cherkasy $\left(10^{\text {th }}\right.$ place $)$ regions, the partial indicators are the highest by the three indicators. In Ivano-Frankivsk region, which in the ranking took the third place, 9 of 13 partial indicators have the values above 0,6 .

The last three places in the ranking took Donetsk, Zaporizhzhia, and Luhansk regions. The main reason for such low indicators, the common for all these regions, - is the high volumes of polluted water emissions into surface waters and emissions of harmful substances into the atmosphere. In addition, in Zaporizhzhia region, there is the lowest forest area and land return, in Luhansk region - the lowest partial indices of agricultural production per 100 hectares volume and inter-regional migration; in Donetsk region - the lowest volume of agricultural production per one person. In general, the gap between the highest and the lowest generalized indicator for the agricultural land use sustainability development assess was 0,403 (2,2 times). 
Table 6

The integral indicator for evaluation of agricultural land use sustainability in the regions of Ukraine

\begin{tabular}{|c|c|c|c|c|c|c|}
\hline \multirow{2}{*}{ Regions } & \multicolumn{2}{|c|}{2006} & \multicolumn{2}{|c|}{2013} & \multicolumn{2}{|c|}{2013 against $2006,+-$} \\
\hline & $I_{i}$ & Place by the rating & $I_{i}$ & Place by the rating & $I_{i}$ & Place by the rating \\
\hline AR of Crimea & 0.423 & 21 & 0.413 & 21 & -0.010 & 0 \\
\hline Vinnytsia & 0.527 & 7 & 0.594 & 5 & 0.067 & -2 \\
\hline Volyn & 0.630 & 2 & 0.700 & 2 & 0.070 & 0 \\
\hline Dnipropetrovsk & 0.422 & 22 & 0.391 & 22 & -0.031 & 0 \\
\hline Donetsk & 0.407 & 23 & 0.374 & 23 & -0.033 & 0 \\
\hline Zhytomyr & 0.501 & 10 & 0.570 & 8 & 0.069 & -2 \\
\hline Zakarpattia & 0.654 & 1 & 0.742 & 1 & 0.088 & 0 \\
\hline Zaporizhzhia & 0.395 & 24 & 0.369 & 24 & -0.026 & 0 \\
\hline Ivano-Frankivsk & 0.525 & 8 & 0.619 & 3 & 0.094 & -5 \\
\hline Kyiv & 0.520 & 9 & 0.569 & 9 & 0.049 & 0 \\
\hline Kirovohrad & 0.462 & 15 & 0.495 & 16 & 0.033 & 1 \\
\hline Luhansk & 0.360 & 25 & 0.339 & 25 & -0.021 & 0 \\
\hline Lviv & 0.489 & 13 & 0.480 & 17 & -0.009 & 4 \\
\hline Mykolaiv & 0.437 & 19 & 0.433 & 20 & -0.004 & 1 \\
\hline Odesa & 0.431 & 20 & 0.451 & 18 & 0.020 & -2 \\
\hline Poltava & 0.485 & 14 & 0.514 & 14 & 0.029 & 0 \\
\hline Rivne & 0.531 & 6 & 0.584 & 7 & 0.053 & 1 \\
\hline Sumy & 0.451 & 17 & 0.505 & 15 & 0.054 & -2 \\
\hline Ternopil & 0.553 & 4 & 0.520 & 13 & -0.033 & 9 \\
\hline Kharkiv & 0.437 & 18 & 0.448 & 19 & 0.011 & 1 \\
\hline Kherson & 0.455 & 16 & 0.548 & 11 & 0.093 & -5 \\
\hline Khmelnytskyi & 0.496 & 11 & 0.588 & 6 & 0.092 & -5 \\
\hline Cherkasy & 0.532 & 5 & 0.568 & 10 & 0.036 & 5 \\
\hline Chernivtsi & 0.619 & 3 & 0.619 & 4 & 0.000 & 1 \\
\hline Chernihiv & 0.491 & 12 & 0.533 & 12 & 0.042 & 0 \\
\hline
\end{tabular}

Source: calculated by the authors

\section{Conclusions}

1. The proposed methodology is developed to rank the stability of the agricultural land use and includes the set of the most important partial criteria.

2. It is found that at the present time, there are many models of the indicators systems, the common element of which is the availability of simple, linking indicators and indicators that point to the distance to the target. However, the anticipated indicators are largely of the controversial nature and they have not received general recognition in the world.

3. The expediency is proved and two methodological approaches for the agricultural land use stability assessment have been made up: the construction of the aggregate indicator, with the help of which it is possible to judge the degree of the land use sustainability at the macro level; the construction of the integral indicator to compare the countries' land use sustainability.

4. The method for determining the aggregate indicator has been developed and the method for determining the integral indicator of the agricultural land use sustainability that takes into account environmental, economic and social aspects of the process and its characteristics in the countries of the post-socialist camp has been improved.

5. According to the given methods, it has been proved that agricultural land use in the countries of the post-socialist camp has a positive dynamics, but the sustainability indicators for all indicators have not achieved yet.

6. In accordance with settlements for solving the problems in the area of agricultural land use, the state should focus on less developed regions where environmental situation is difficult (Crimea, Dnipropetrovsk, Donetsk, Ivano-Frankivsk, and Luhansk regions), productivity (Crimea, Zaporizhzhia, Luhansk, Zakarpattia, and Kyiv regions) and land return (Crimea, Zaporizhzhia, Luhansk, and Kherson regions) reduced, slowed population growth (Poltava, Sumy, Khmelnytskyi, Cherkasy, and Chernihiv regions) and have an excessive migration (Zakarpattia, Kirovohrad, Luhansk, and Kherson regions). 


\section{References:}

UNU (2017). Sustainable Development Goals 2016-2030. Retrieved from: http://www.un.org.ua/ua/ tsili-rozvytku-tysiacholittia/tsili-staloho-rozvytku

FAO (2017). The global strategy to improve the agricultural and rural statistics. Retrieved from: http://gsars.org/en/ Meadows, D., Meadows, D., Randers, J. (2004). Limits to growth. The 30-year update. Chelsea Green Publishing. Harlem Brundtland, Gro. (2002). World summit on sustainable development. BMJ. 325. 399. 10.1136/ bmj.325.7361.399.

Ashby, M. (2015). Materials and sustainable development ( $1^{\text {st }}$ Edition).

Droste, N., Kuikman, P. and others (2016). Steering innovations towards a green economy: understanding government intervention. Journal of Cleaner Production, 135, 426-434.

Fiorella, K., Chen, R., Milner, E. (2016). Agricultural interventions for improved nutrition: a review of livelihood and environmental dimensions. Global Food Security, 8, 39-47.

Kotykova, O. (2012). Methodological and methodical bases of complex evaluation of sustainable development of agricultural land use. Collection of Scientific Works SWorld. Odesa: Kyprienko.

Cabinet's of Ministers of Ukraine Resolution (2015). The Method of the state regional policy implementation monitoring and evaluation. Retrieved from: http://zakon2.rada.gov.ua/laws/show/856-2015-\%D0\%BF/ paran58\#n58

Cabinet's of Ministers of Ukraine Resolution (2015). The procedure of the state regional policy implementation monitoring and evaluation. Retrieved from: http://zakon2.rada.gov.ua/laws/show/856-2015-\%D0\%BF

Ministry of regional development, construction and housing and communal services of Ukraine. Department of regional development (2016). The socio-economic development monitoring in 2015. Retrieved from: http://www.minregion.gov.ua/wp-content/uploads/2016/03/Otsinka-sotsialno-ekonomichnogo-rozvitkuregioniv-za-2015-r.-prezentatsiyni-materiali.pdf 